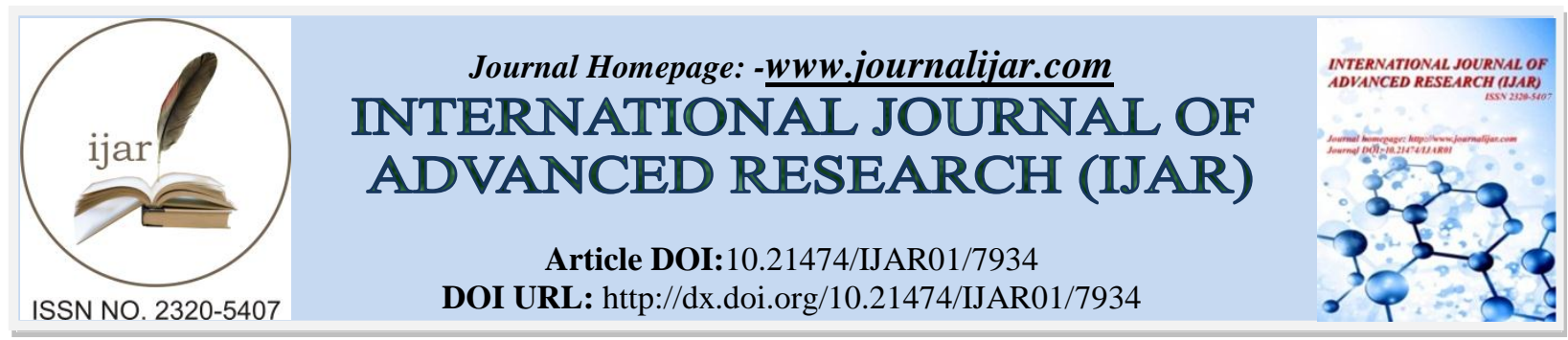

RESEARCH ARTICLE

\title{
COMPARATIVE ANALYSIS OF COMPETITIVENESS TOURISM BETWEEN CHINA AND MALI.
}

1. Master student, shanghai university.

Aboubacar Diarra ${ }^{1}$ and Xu Jinye ${ }^{2}$.

2. Associate professor, shanghai university.

\section{Manuscript Info}

Manuscript History

Received: 14 August 2018

Final Accepted: 16 September 2018

Published: October 2018

Keywords:-

Mali, tourism, landlocked, poverty etc.

\begin{abstract}
Since the 1960s, the world's tourism industry has entered an era of rapid development. The tourism industry of China and the Republic of Mali has also developed rapidly. We can find that the status of tourism in the national economy has been significantly improved, and gradually developed into a national strategic pillar industry. In the 1960s, African countries were liberated from the oppression of colonialism and mastered their own sovereignty. While developing their economies, they also fully realized the enormous impetus of tourism to the economy and invested heavily in the development of tourism resources and tourism. This paper makes a comparative analysis ofthe tourism distribution, competitiveness and other aspects, and clarifies the economic benefits of tourism to China and Mali.
\end{abstract}

Copy Right, IJAR, 2018,. All rights reserved.

\section{Introduction:-}

\section{Research Background:-}

Since the reform and opening up, the tourism industry of China and the Mali has developed rapidly. We can find that the status of tourism in the national economy has been significantly improved, and gradually developed into a national strategic pillar industry. Tourism is a new industry with wide employment scope, high foreign exchange earning efficiency and large value-added space.

As an ancient and civilized continent on the earth, Africa's tourism industry mainly rose after the independence movement. Especially since the 1970s, African tourism has entered a period of rapid development, from North Africa to sub-Saharan African countries. The development of African tourism has made remarkable achievements in the international tourism industry, and tourism has become a new pillar industry in Africa. In just a few decades, the number of international tourists and tourism revenue in Africa showed a general upward trend. In recent years, the global tourism industry is affected by terrorist attacks, regional political instability, economic conflicts, natural disasters and other factors, the growth of tourism is slowing down. However, the growth rate of tourism worldwide remains basically stable. Among them, the development of Africa's tourism industry is a new force. Statistics show that in 2017, China's total tourism revenue reached 54,000 billion yuan, more than 10 times the 2001 figure of less than 500 billion yuan. It can be said that in the past 20 years, China's tourism industry has developed very rapidly, has become an indispensable part of China's economic development, and has made important contributions to China's economic development. Mali, as a landlocked country in West Africa, has a long history and culture and rich tourism resources. Since 2007, the Malian government has begun to focus on the development of tourism. In 2007, Mali received 250 thousand foreign tourists, earning 175 million US dollars for the country. In 2017, Mali's tourism revenue amounted to 2 billion 150 million US dollars, accounting for $15.3 \%$ of its national income. 
However, compared with China's tourism industry, Mali's tourism industry still has some room for development, there are some areas worthy of further optimization.

As the process of economic globalization continues to intensify, China and Mali, as members of the global village, are bound to be subject to competition and influence from other countries in the world. In the face of increasingly fierce nationalization competition, how China and Mali cope with the challenges and improve their international competitiveness has become the focus of theoretical circles and society in recent years. In particular,through the analysis of the status quo of tourism in China and Mali, this paper makes a comparative analysis of the development process, development model, distribution, competitiveness and other aspects, and makes clear the economic benefits of tourism to China and Mali. Subsequently, through comparative analysis, this paper hopes to find out the shortcomings of Mali's tourism development, especially the gap between Mali and China's tourism industry, hoping to learn from the relevant experience of China's tourism industry, and constantly optimize and improve, so as to promote the further development of Mali's tourism and enhance the international tourism industry in Mali. Competitive power.

\section{Literature Review:-}

For a country's economic development, the importance of tourism gradually emerged. Since the 1960s, as a tourist gateway, inbound tourism has developed rapidly in western developed countries. Foreign scholars began to realize the importance of tourism gradually, and thus launched a centralized qualitative study on the impact and importance of tourism. Stanfield (1964) found that the development of tourism may lead to urban and rural imbalance. He first recognized and put forward the importance of urban tourism. Then scholars began to pay attention to the importance and impact of tourism on cities. Geoffrey (1983) discussed the impact of national tourism development on social transformation. Ashworth $\left(1990^{1}, 1992^{2}\right)$ first studied the development of tourism in historic countries, and then proposed that the city is a tourist destination, not only economic, cultural, political center, but also a tourist center, tourism plays an important role in urban development. Mullins (1991) 3 proposed that urban tourism is a new type of urbanization based on the sales and consumption of pleasure. The 1970s was the golden age for the rapid development of Japanese residential housing industry. With the rural tourism sweeping through Japan, the residential housing industry in various scenic spots developed vigorously. Yuan Jun and Zhang Meng(2011) ${ }^{4}$ put forward three typical modes of integration development of cultural industry and tourism industry according to the theory of industrial chain and industrial integration. The comparative study shows that the integration of cultural industry and tourism industry in Shenzhen has achieved initial results, but there are many problems, such as the incomplete industrial chain structure, the single product structure of tourism and cultural industry integration, and the difficulty of extending the life cycle of theme parks.Fang B et al. (2016) ${ }^{5}$ studied the hotel chain model in the tourism industry, and explored whether the culture of the host country affected the market penetration of the hotel chain in its hotel industry. The paper collects data from various countries and calculates the share of hotels and rooms in 132 countries. Among the 65 countries, there are available data on Hofstede's four cultural dimensions (power distance, individualism, masculinity and uncertainty avoidance), and 78 countries have data on two other dimensions (long-term orientation and indulgence) that are used for analysis. The conclusion shows that the culture of host country will affect the market penetration of chain hotels in their hotel industry. Zhang Jing (2017) ${ }^{6}$ conducted a study on the new model of tourism industry -- home stay. Nowadays, a new tourism-related industrycommercial lodging (or lodging, hereinafter referred to as the same), has become a global trend of lodging.

After demonstrating the importance of tourism to a country and a city, scholars at home and abroad begin to pay attention to what factors affect the development of tourism. Only by finding relevant factors and constantly optimizing can we guarantee the long-term development of tourism.

${ }^{1}$ Denny P, Swift S, Connor F, et al. An SRY-related gene expressed during spermatogenesis in the mouse encodes a sequence-specific DNA-binding protein[J]. Embo Journal, 1992, 11(10):3705-12.

${ }^{2}$ Ashworth G J, Voogd H. Selling the city: marketing approaches in public sector urban planning.[J]. 1990.

${ }^{3}$ Litovitz, T.A, Meister, et al. Mechanisms of microwave-induced damage in biologic materials. Annual report, 22 Sep 89-21 Sep 90[J]. 1991.

${ }^{4}$ Yuan Jun, Zhang Meng. Model Construction of Interactive Development between Tourism and Cultural Industry in Shenzhen [J].Journal of Shenzhen University (Humanities and Social Sciences), 2011, 28 (2): 17-21.

${ }^{6}$ Zhang Jing. Research on the development of tourism in Nanjing commercial residential quarters [D]. Anhui University, 2017. 
Tan S H (2017) ${ }^{7}$ analyzed the economic consequences of environmental factors in different regions based on the data of airlines, casinos, hotels and restaurants in the tourism industry. The study found that from 2003 to 2014, environmental factors can have a positive impact on the financial performance of tourism enterprises. Guimares $(2016)^{8}$ takes tourism industry in Brazil as the research object, and analyzes wage differentials caused by gender differences. The study found that gender discrimination existed in tourism industry in Brazil. That is to say, women are paid less than men in the travel industry. This phenomenon is unfair, but it also reflects the difference between male and female labor force. This research provides academic value for future improvement. The publicity of tourism can affect the development of tourism. If the publicity channel is wide and the publicity is strong, it may bring potential customers to scenic spots. Ding Shuo $(2017)^{9}$ took the big data as the research background, and discussed the propaganda problem of the tourism industry. Wan-In Lee, Bharath M. Josiam (2004) ${ }^{10}$ studied the influencing factors of MICE tourism competitiveness and the corresponding evaluation model. Larry Dwyer et al. $(2004)^{11}$ discussed the evaluation model of tourism destination competitiveness. GooroochurnNishaal, SugiyartoGuntur $(2005)^{12}$ used eight indicators to evaluate regional tourism competitiveness, including price, openness, tourism resources, technology, various parts of the system, environmental and social development and human resources. Carlos Mario Gomez, Javier Lozano $(2008)^{13}$ focuses on the impact of long-term welfare and tourism environmental policies on tourism economic development. Qian Lei et al. (2012) ${ }^{14}$ assessed the development level of China's tourism industry in 2000 by choosing six statistical indicators, including the number of domestic tourists, the proportion of tourism employees in the total number of social employees, the number of inbound tourists, the domestic tourism revenue, the proportion of tourism revenue to GDP, and the foreign exchange income of tourism. The difference of tourism between provinces and cities between 2010 and 2010.

With the continuous development of globalization, African tourism has become the choice of many tourists. Domestic and foreign scholars have conducted relevant research on African tourism. Since the 1950s, countries around the world have set up special research institutions to conduct comprehensive research on Africa. In addition to studying African history, economy, culture and other aspects, these institutions also include the study of African tourism. With the rapid development of African tourism, all countries have realized the necessity of African tourism research, especially with the number of developed countries such as Europe and the United States increasing year by year to Africa tourism, thus triggering the enthusiasm of countries for African tourism research, research investment in Africa is increasing, and the scale is gradually expanding. Tang Lanlan $(2010)^{15}$ believes that Africa has a vast territory, a long history, ancient cultural heritage, forming a unique African customs and traditions. In 56 countries and regions, every country has special and charming tourist resources. Natural scenery can be painted everywhere, and the humanities resort has a long history. The study also found that the development of tourism in Africa was uneven. According to the results of the comprehensive ranking, tourism development in northern Africa is relatively fast, while in southern Africa, except South Africa, the tourism development in other countries is relatively backward. According to the survey, tourists to Africa will generally choose the more developed economy, culture and convenient transportation in the north, while resource-rich and economically backward southern Africa is relatively cold door, many countries even today are still rare visitors.

\footnotetext{
${ }^{7}$ Tan S H, Habibullah M S, Tan S K, et al. The impact of the dimensions of environmental performance on firm performance in travel and tourism industry.[J]. Journal of Environmental Management, 2017, 203(Pt 1).

${ }^{8}$ Guimarães C R F F, Silva J R. Pay gap by gender in the tourism industry of Brazil[J]. Tourism Management, 2016, 52:440-450.

${ }^{9}$ Ding Shuo. Research on marketing communication strategy of online tourism industry under the background of big data [D]. Jilin University, 2017.

${ }^{10}$ Lee W I 1. A framework for assessing national convention tourism competitiveness: an exploratory study[J]. J for International Business \& Entrepreneurship Development, 2004, 2(2):105-112.

${ }^{11}$ Dwyer L, Mellor R, Livaic Z, et al. Attributes of destination competitiveness: a factor analysis.[J]. Tourism Analysis, 2004, 9(1-2):91-101.

${ }^{12}$ Nishaal G, Nishaal G, Nishaal G. Sugiyarto Guntur: Competitiveness indicator in the travel and tourism industry[J]. Tourism Economics, 2005, 11(1):25-43.

${ }^{13}$ Gómez C M, Lozano J, Rey-Maquieira J. Environmental policy and long-term welfare in a tourism economy[J]. Spanish Economic Review, 2008, 10(1):41-62.

14 Qian Lei, Wang Yuming, Wu Wenjia. Provincial and Regional Differences and Changes in Tourism Development in China [J].Journal of Tourism, 2012, 27 (1): 31-38.

${ }^{15}$ Tang Lanlan. African tourism resources and their attractiveness [D]. Zhejiang Normal University, 2010.
} 
To sum up, we can see that the research on Tourism in Mali is very scarce both at home and abroad. This paper takes China as the object of comparative study, studies Mali's tourism industry from various angles, and compares and analyzes the gap between China's tourism industries.

\section{Comparative analysis of competitiveness:-}

With the continuous development of tourism in the world, the study of tourism destination competitiveness has become a hot topic. National tourism competitiveness is very important for a country to maintain and strive for a larger tourism market. There is a significant relationship between national tourism competitiveness and international tourists' perceptual image, emotional image, tourism satisfaction, loyalty and recommendation intention ${ }^{16}$. Among them, the overall national tourism image composed of national tourism perception image and emotional image is the basis of influencing national tourism competitiveness, and is the antecedent variable of influencing tourists' satisfaction, loyalty and recommendation intention. Improving the satisfaction, loyalty and recommendation of international tourists is the fundamental way to expand the international tourism market and enhance the competitiveness of national tourism.

\section{Competitiveness of China's tourism industry:-}

China is in a very important position in the world economy. In the process of continuous development, China's tourism industry has been subjected to competition from all over the world. China's economic strength is very strong, with this strong foundation, China's tourism can maintain a higher competitiveness. China and ASEAN are geographically similar, and the impact of ASEAN countries on China's tourism industry is more direct. Therefore, it will be of great practical significance to analyze China's tourism competitiveness in the face of ASEAN countries.

As an important industrial sector, tourism competitiveness of each country is the productivity of the comparison between tourism and foreign tourism. The advantages of tourism competitiveness between China and other countries are mainly embodied in the preferential development policies of governments and the competitive advantages of tourism prices. At present, China and other countries in the world are implementing regional service trade liberalization and tourism integration strategies to promote regional tourism competitiveness by strengthening regional tourism cooperation. In terms of tourism environment and infrastructure, China's tourism enterprises rank 61 st in the world in terms of environment and infrastructure construction. The world rankings of aviation facilities, land transportation facilities, tourism facilities, communication and information facilities and tourism price competitiveness are 36, 45, 113, 63 and 11 respectively. From these rankings, tourism facilities are the bottlenecks to break through in the development of tourism in China. Singapore ranks first in the world in terms of infrastructure, including land transport facilities, aviation facilities and communications and information facilities, ranking third, tenth and eighteenth respectively. The land transport facilities in Malaysia rank the fifteenth in the world. Thailand and Malaysia have the twenty-fifth, thirty-first largest aviation facilities in the world. However, the development of aviation facilities, land transportation facilities, tourism facilities and communication and information facilities in other less developed countries are relatively lagging behind, especially in Vietnam and Cambodia, which seriously hinder the development of tourism. From the perspective of tourism resources, China ranks ninety-third in the world in terms of competitiveness in manpower, culture and natural resources. Among them, it involves the popularity and service attitude of the people to foreign tourists and the competitiveness of the national tourism image represented by the degree of community openness. China's performance is very inadequate, ranking 120th in the world, lagging behind. All ASEAN countries and developed countries in Europe and the United States.

\section{Competitiveness of Mali's tourism industry:-}

Africa is a civilized and ancient continent with a long history and splendid culture. The whole continent is vast and beautiful. Rich and unique tourism resources attract tens of thousands of tourists from all over the world to visit, investigate and explore every year, thus promoting the growth of tourism economy in African countries, and thus promoting the development of national economy. Africa's tourism resources are unique and have formed a certain scale after decades of development. All countries are actively exploring the tourism policy suited to their national

\footnotetext{
${ }^{16}$ Zhang Guanghai, Li Xue.A review of tourism competitiveness at home and abroad[J].Journal of Ocean University of China (Social Science Edition), 2006 (5): 28-32.
} 
conditions and making the tourism industry develop rapidly. Among the numerous countries in Africa, South Africa, Morocco and Kenya are the most prominent ones. These countries are strong opponents of Mali's tourism industry ${ }^{17}$.

Next, take Morocco, Africa as an example, analyze the competitiveness of Mali's tourism industry. Morocco is rich in tourism resources and has developed tourism industry. Tourism income is one of the main sources of foreign exchange in Morocco.

Compared with Morocco, Mali's tourism industry lacks certain reputation. The publicity is not in place, which greatly reduces the popularity of Mali tourist attractions. When tourists choose to travel to Africa, they may choose the Rabat Palace in Morocco instead of the Askiah Mausoleum in Mali. Because they know little about the latter. From the perspective of rational economists, when people take action, they often want to reduce the degree of information asymmetry and choose projects with lower risk. In addition, from the perspective of tourism resources development, competitiveness analysis, we can find that Morocco's tourist attractions have a complete infrastructure, such as transportation routes, for tourists to provide a great convenience for tourism activities. However, Mali mainly depends on highways, and the layout of highway lines has not yet covered the whole country. This may result in a tourist wanting to go from one scenic spot to another without finding a suitable mode of transportation. This situation will greatly reduce the competitiveness of Mali's tourism industry. Compared with other developed countries, Mali's tourism competitiveness is even weaker.

\section{Comparative analysis:-}

From the perspective of world tourism, China's tourism industry has strong competitiveness and is at a medium level. Mali's tourism industry lacks competitiveness. The lack of competitiveness of Mali's tourism industry can be attributed mainly to political turmoil and imperfect tourism system. In recent years, Mali has been facing a severe crisis of northern secession. The terrorist from the north have gone south and launched attacks on the areas under the control of the Malian army. The people's energy is mainly on survival, and they have no time to take into account such leisure activities as tourism. In addition, Mali's education is very backward compared with China. Especially, tourism vocational education is developing slowly. If the quality of the practitioners is low, even the tourists' impression of the destination is not good. Most visitors to Mali believe that the limited knowledge level of Mali's tourism practitioners, resulting in communication barriers, service quality evaluation is low. Therefore, Mali's competitiveness in tourism is lower than that in China, which needs improvement.

\section{Comparative analysis of economic benefits:-}

To some extent, the existence of an industry is due to its economic benefits. Industries that fail to bring economic benefits to the country will eventually be eliminated by society. Therefore, to explore the economic benefits of the tourism industry, we can find the economic benefits of Mali's tourism gap, and for the optimization of Mali's tourism industry to prepare sufficient reasons.

\section{The economic benefits of China's tourism industry:-}

From the perspective of absolute value, tourism revenue represents the development of a country's tourism industry. According to the trend analysis of time series, we can further find the trend of economic benefits. The total income of China's tourism industry is a comprehensive index to measure the economic benefits of tourism. Since 2010, China's tourism industry has been developing for a long time. During the seven years from 2010 to 2016, the total revenue of China's tourism industry increased year by year, and the growth rate was faster and faster. The total income of China's tourism industry can be divided into domestic tourism income and international tourism income. As can be seen from the chart, since 2010, China's domestic tourism revenue has increased year by year, the growth trend is very obvious. At the same time, China's international tourism revenue remained stable during the period from 2010 to 2014. This may be related to the impact of the financial crisis. After 2015, China's international tourism revenue has shown a significant growth trend, which greatly increased the total revenue of China's tourism industry, bringing about sufficient economic benefits ${ }^{18}$.

\footnotetext{
${ }^{17}$ Krstic B, Jovanovic S, Jankovicmilic V, et al. Examination of travel and tourism competitiveness contribution to national economy competitiveness of sub-Saharan Africa countries[J]. Development Southern Africa, 2016, 33(4):116.

${ }^{18} \mathrm{Wu}$ Shanshan, Wu Jinfeng, Wang Yundi, et al. Study on the Relationship between National Tourism Competitiveness and Tourist Perception: A Case Study of European and American Tourists in China [J].Resources and Environment in Arid Areas, 2015, 29 (4): 202-208.
} 


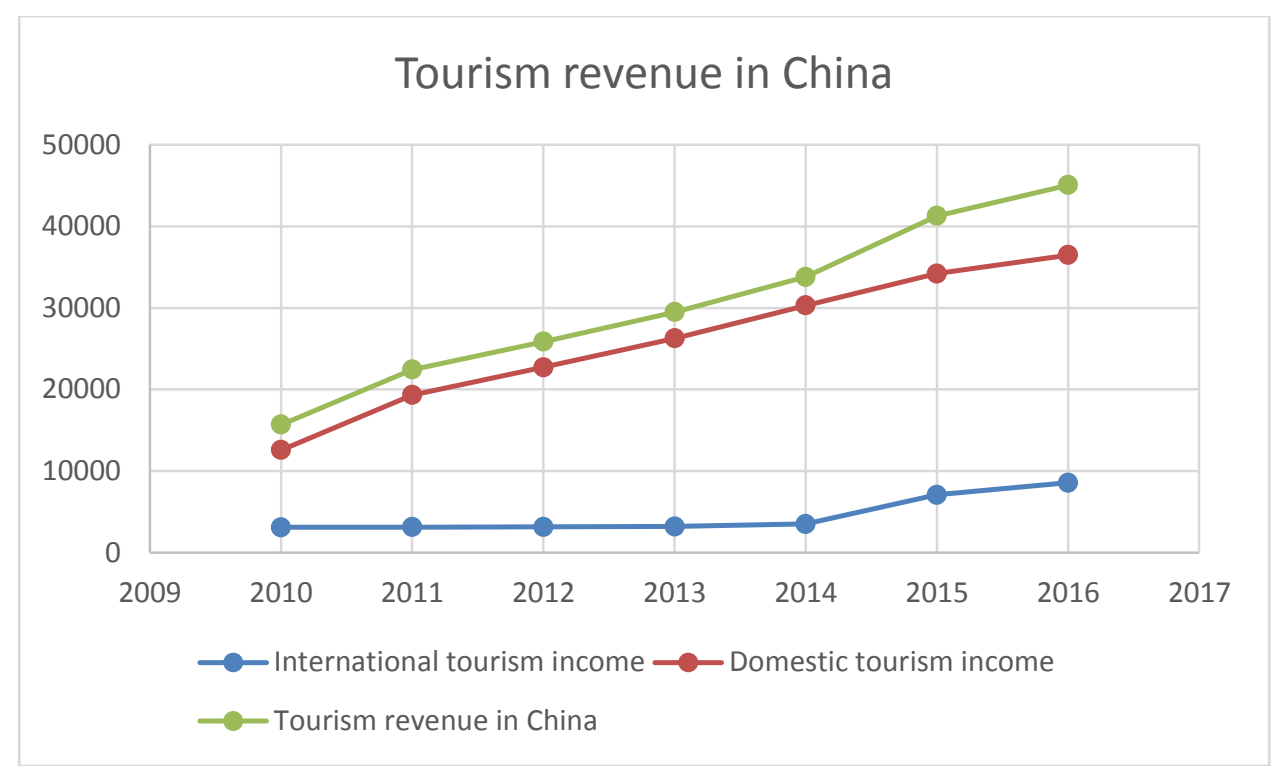

Fig3.3:-Tourism revenue in China

Data Source: CSMAR database

From the perspective of relative value, the proportion of an industry in GDP determines the position of the industry in each industry. A country will strongly encourage higher industries to improve the economic efficiency of the industry. After China's tourism industry has entered the stage of comprehensive development, China's gross national economy has increased accordingly. On the one hand, the growth of China's gross national economy can be partly attributed to the development of China's tourism industry. On the other hand, the proportion of the total income of China's tourism industry in the gross national economic value shows a tortuous upward trend, indicating that China's tourism industry has made greater and greater contributions to China's economic development. From the statistics of relative value, we can see that China's tourism industry is becoming more and more important, and its economic benefits are constantly improving.

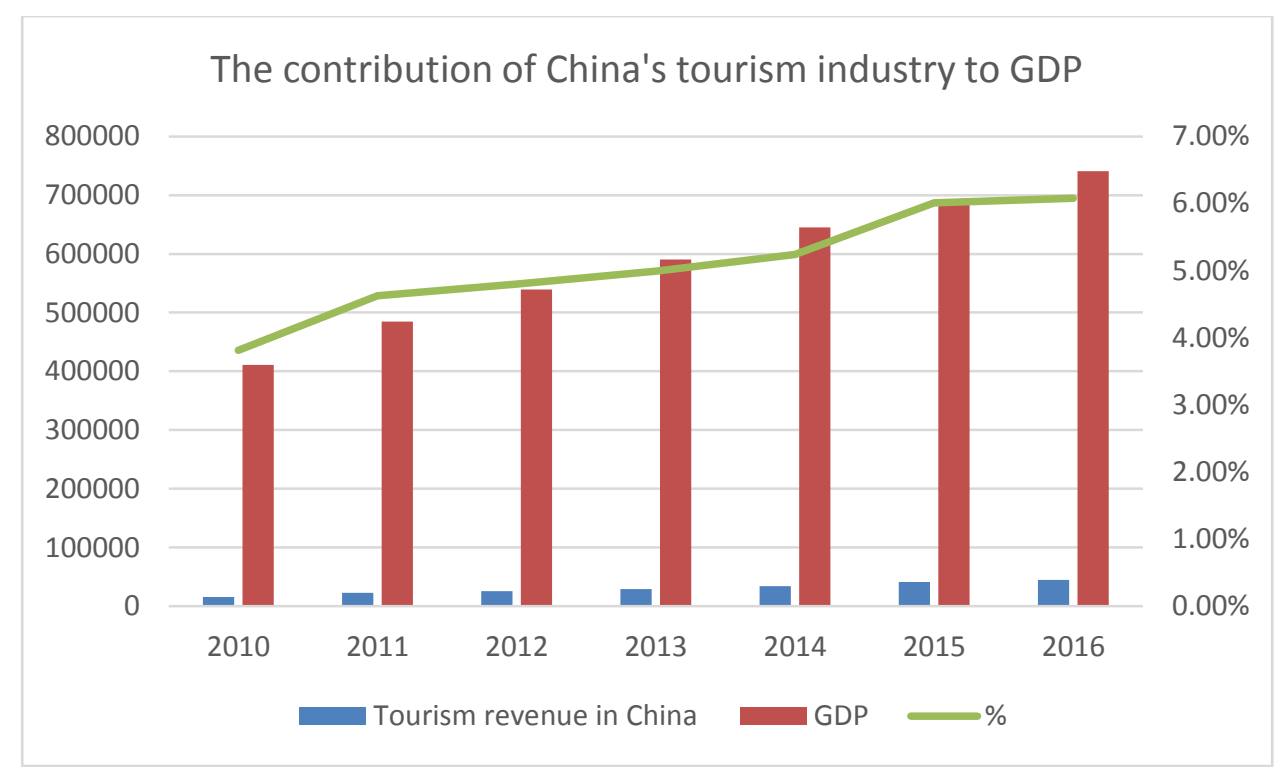

Fig 3.4 Contribution of China's tourism industry to GDP

Data Source: CSMAR database 


\section{Economic benefits of Mali's tourism industry:-}

Mali is a relatively backward country. The primary industry occupies an important part of the national economy. The Malian government recognizes that, as industry and agriculture are relatively backward, it is of great practical significance to develop the national economy and tourism. In addition to providing a large number of employment opportunities and improving the lives of people who are often in cyclical poverty or are almost marginalized, tourism is an important channel for the state to earn foreign exchange ${ }^{19}$. Tourism helps to improve the balance of payments in poor countries. In addition, international tourists to Mali tourism, can expand Mali's exchanges with the world, so that the outside world has a better understanding of it, thus laying the foundation for further attracting foreign investment. To this end, the Malian government has raised the development of tourism to a strategic height, set up a special tourism development zone, the goal is to build Mali into a leading tourism industry in Africa in the future, hoping to rely on the development of tourism to promote the overall recovery and growth of the national economy. Therefore, we must pay attention to the economic benefits brought by Mali's tourism industry.

As can be seen from the chart, from 2010 to 2016, Mali's tourism industry is constantly adjusting, the total revenue of tourism is increasing year by year. By 2016, Mali's international tourism revenue exceeded its domestic tourism revenue for the first time. This shows that Mali's tourism structure has changed from domestic tourism to international tourism. This trend is quite right for Mali. Mali is an economically underdeveloped country with limited domestic consumption capacity. Only by attracting international tourists can it ensure the continuous development of tourism.

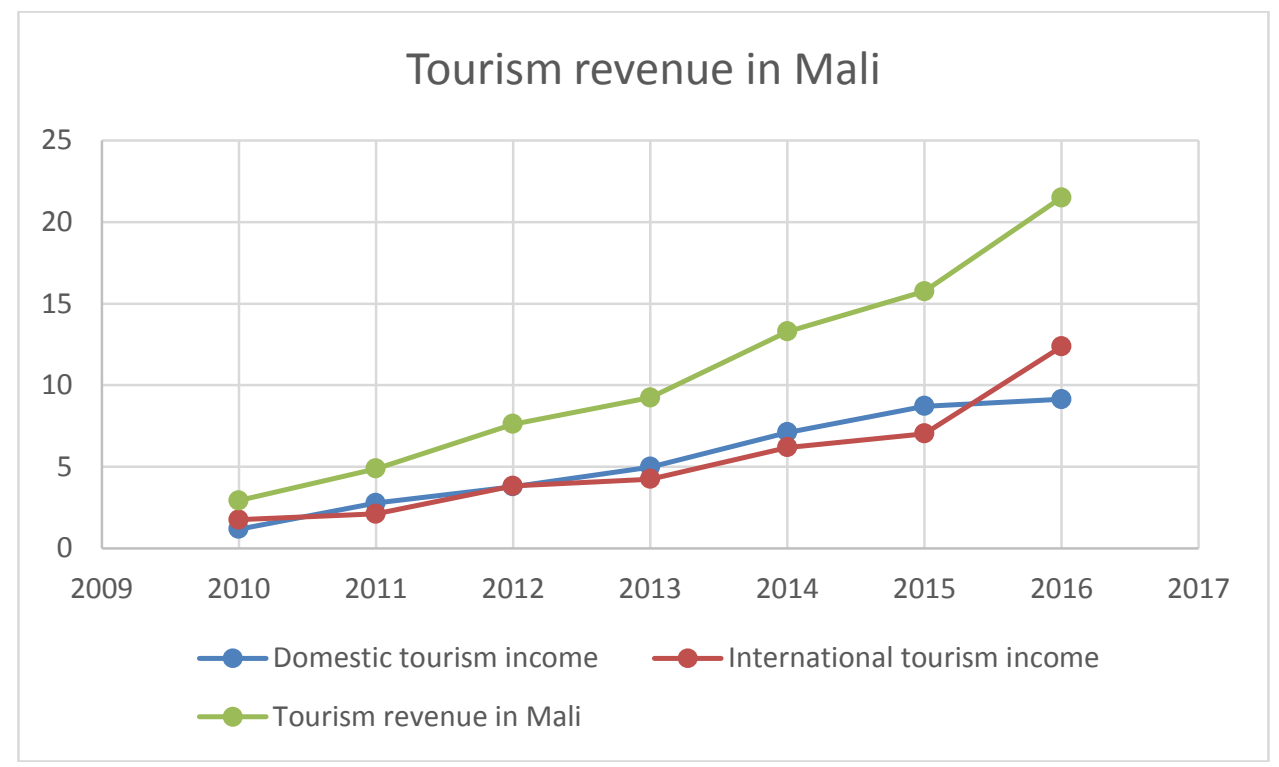

Fig 3.5 Tourism revenue in Mali

Data Source:World Tourism Yearbook

The economic value of Mali's tourism industry should also be reflected in the gross national product. Mali's political situation is in a state of instability, from 2010 to 2016, Mali's gross national product showed volatile changes. Mali's GDP peaked in 2014 and rebounded slightly in 2016 after declining in 2015. The contribution of Mali tourism to GDP has shown a steady upward trend. Although the growth rate decreased from 2012 to 2013, it has continued to increase since 2014.

\footnotetext{
${ }^{19}$ Liu Xu. Research on the economic effects and development strategies of African Tourism [D]. Zhejiang Normal University, 2009.
} 




Fig 3.6:- Mali tourism's contribution to GDP

Data Source:World Tourism Yearbook

\section{Comparative analysis:-}

Economic value is reflected not only in absolute value, but also in relative value. From the perspective of absolute value, the total revenue of Mali's tourism industry is far lower than that of China's tourism industry. This may be due to the lack of infrastructure in Mali. In addition to their special preference for tourist attractions, tourists are also increasingly demanding the basic and supporting facilities of tourist destinations, such as whether the traffic conditions are good, whether accommodation is convenient and whether leisure and entertainment can be satisfied. In terms of relative value, Mali's total tourism revenue accounts for a higher proportion of the gross national economy than China's. This is mainly because Mali's primary and secondary industries are developing slowly and lack of advanced science and technology. At the same time, the development of tourism is much easier.

\section{Conclusion:-}

Generally speaking, Mali's tourism resources are very rich, but compared with China, its development efforts are limited. This is mainly due to the fact that Mali's economic level is relatively backward. Mali's tourism industry is less attractive worldwide, and international tourists are less willing to make Mali their destination. As far as Mali is concerned, the lack of tourism-related supporting services has greatly frustrated tourists'enthusiasm for tourism. The slow development of tourism is directly related to Mali's underdeveloped economy, politics and culture, and the backwardness of supporting facilities also has a negative impact on Mali's tourist attractiveness.

\section{Reference:-}

1. Ali S M, Moghevemi S, Zailani S. Malaysian Islamic medical tourism market: A SWOT analysis, Journal of Islamic Marketing, Emerald, Vol 8, Issue 3[J]. Journal of Islamic Marketing, 2017, 8(3).

2. Ashworth G J, Voogd H. Selling the city: marketing approaches in public sector urban planning.[J]. 1990.

3. Ashworth G J. Tourist-historic city.[J]. 1990.

4. Boes K, Buhalis D, Inversini A. Smart tourism destinations: ecosystems for tourism destination competitiveness[J]. International Journal of Tourism Cities, 2016, 2(2):108-124.

5. Ben Cousins, ThembelaKepe. Decentralisation when land and resource rights are deeply contested: A case study of the Mkambati eco-tourism project on the wild coast of South Africa[J]. European Journal of Development Research, 2004, 16(1):41-54.

6. Bank W. Africa Region Tourism Strategy : Transformation through Tourism - Harnessing Tourism for Growth and Improved Livelihoods[J]. World Bank Other Operational Studies, 2011.

7. Buhalis D, Viveiros O. Urban tourism[J]. Annals of Tourism Research, 2000, 27(1):229-231.

8. Chirisa I, Muchenje B, Kawadza S T. A study on the dilemmas of resource utilization and tourism in Africa[J]. Chinese Journal of Population, Resources and Environment, 2014, 12(2):129-136.

9. Christie I T, Crompton D E. Tourism in Africa.[J]. World Bank Other Operational Studies, 2001. 
10. Christie I T, Crompton D E. Tourism in Africa.[J]. World Bank Other Operational Studies, 2001.

11. Ding Shuo. Research on marketing communication strategy of online tourism industry under the background of big data [D]. Jilin University, 2017.

12. Dilek S, Kesgingöz H. SWOT Analysis of Safranbolu City In Terms Of Tourism[J]. 2016, 5(1):54.

13. Dwyer L, Mellor R, Livaic Z, et al. Attributes of destination competitiveness: a factor analysis.[J]. Tourism Analysis, 2004, 9(1-2):91-101.

14. Dwyer L, Forsyth P, Spurr R. Inter-industry effects of tourism growth: implications for destination managers.[J]. Tourism Economics, 2003, 9(9):117-132.

15. Dwyer L, Kim C. Destination Competitiveness: A Model and Determinants [J]. Current Issues in Tourism, 2003, 6(5).

16. Dieke P U C, Harrison D. Human resources in tourism development: African perspectives.[J]. Human Resources in Tourism Development African Perspectives, 2001:61-75.

17. Denny P, Swift S, Connor F, et al. An SRY-related gene expressed during spermatogenesis in the mouse encodes a sequence-specific DNA-binding protein[J]. Embo Journal, 1992, 11(10):3705-12.

18. Elsayed K, Paton D. The impact of environmental performance on firm performance: static and dynamic panel data evidence[J]. Structural Change \& Economic Dynamics, 2005, 16(3):395-412.

19. Franzoni S, Pelizzari C. Weather Risk Management in Tourism Industry[J]. Symphonya Emerging Issues in Management, 2016.

20. Fang B, Qiang Y, Law R. Effect of sharing economy on tourism industry employment.[J]. Annals of Tourism Research, 2016, 57:264-267.

21. Franzoni S, Pelizzari C. Weather Risk Management in Tourism Industry[J]. Symphonya Emerging Issues in Management, 2016.

22. Fotiadis A, Yeh S S, Huan T C T C. Applying configural analysis to explaining rural-tourism success recipes 々 J J]. Journal of Business Research, 2016, 69(4):1479-1483.

23. Ganguli S, Ebrahim A H. A qualitative analysis of Singapore's medical tourism competitiveness[J]. Tourism Management Perspectives, 2017, 21:74-84.

24. Guimarães C R F F, Silva J R. Pay gap by gender in the tourism industry of Brazil[J]. Tourism Management, 2016, 52:440-450.

25. Gómez C M, Lozano J, Rey-Maquieira J. Environmental policy and long-term welfare in a tourism economy[J]. Spanish Economic Review, 2008, 10(1):41-62.

26. Go F M, Govers R. Integrated quality management for tourist destinations: a European perspective on achieving competitiveness.[J]. Tourism Management, 2000, 21(1):79-88.

27. GuoLaixi, Wu Bihu, Liu Feng, et al. Classification and Type Evaluation of Tourism Resources in China [J].Journal of Geography, 2000, 55 (3): 294-301.

28. Holzner M. Tourism and economic development: The beach disease?[J]. Tourism Management, 2011, 32(4):922-933.

29. Huybers T, Bennett J. Environmental Management and the Competitiveness of Nature-Based Tourism Destinations[J]. Environmental \& Resource Economics, 2003, 24(3):213-233.

30. Johnston R J. City and society : an outline for urban geography[M]. Hutchinson, 1984.

31. Krstic B, Jovanovic S, Jankovicmilic V, et al. Examination of travel and tourism competitiveness contribution to national economy competitiveness of sub-Saharan Africa countries[J]. Development Southern Africa, 2016, 33(4):1-16.

32. Katircioglu S T. TESTING THE TOURISM-LED GROWTH HYPOTHESIS: THE CASE OF MALTA[J]. ActaOeconomica, 2009, 59(3):331-343.

33. Kim H J, Chen M H, Jang S C. Tourism expansion and economic development: The case of Taiwan[J]. Tourism Management, 2006, 27(5):925-933.

34. Kontogeorgopoulos N. Accommodation employment patterns and opportunities[J]. Annals of Tourism Research, 1998, 25(2):314-339.

35. King B, Pizam A, Milman A. Social impacts of tourism: Host perceptions[J]. Annals of Tourism Research, 1993, 20(4):650-665.

36. Krugman P R. Increasing Return and Economic Geography[J]. Journal of Political Economy, 1991, 99(3):483499. 